\title{
Notícia Bibliográfica: Sobre a obra Curso de Direito Constitucional, de Ana Paula de Barcellos (Forense, 2018)
}

BARCELLOS, Ana Paula de. Curso de Direito Constitucional. Rio de Janeiro: Forense, 2018, $636 \mathrm{p}$.

\section{Felipe Pereira Maroubo}

Mestrando em Direito Público pela Universidade do Estado do Rio de Janeiro (UERJ). Bacharel em Direito pela Universidade Federal de Uberlândia (UFU) com mobilidade internacional pela Universidade do Porto, Portugal. Advogado. E-mail: fmaroubo@hotmail.com

Ana Paula de Barcellos é Professora Titular de Direito Constitucional da Faculdade de Direito da Universidade do Estado do Rio de Janeiro (UERJ), Mestre e Doutora em Direito pela mesma instituição e possui Pós-Doutorado pela Universidade de Harvard. Ademais, é advogada e VicePresidente da Comissão de Direito Constitucional da Ordem dos Advogados do Brasil - Seccional do Rio de Janeiro (OAB/RJ).

Cumpre ressaltar, ainda, que é autora de outros prestigiados livros jurídicos, dentre os quais estão, sem pretensão de indicação de um rol integral, as obras A eficácia dos princípios constitucionais: o princípio da dignidade da pessoa humana (2002); Ponderação, Racionalidade e Atividade Jurisdicional (2005); e Direitos Fundamentais e Direito à Justificativa: Devido Procedimento na Elaboração Normativa (2016).

Em seu mais novo livro, Curso de Direito Constitucional (2018), a autora apresenta as principais questões subjacentes ao direito constitucional brasileiro com uma perspectiva abrangente, recente, clara e, ao mesmo tempo, profunda, da Constituição de 1988. Assim, o intuito da obra é reunir, de um lado, a necessidade de compreensão do texto e do sistema da Constituição e, de outro, traçar o modo como os dispositivos constitucionais têm sido interpretados e aplicados ao longo das últimas três décadas. 
O livro é dividido em quatorze capítulos. Nesta oportunidade, para efeitos meramente expositivos, considero que há cinco grandes grupos temáticos.

Os Capítulos iniciais, de 1 a 5, possuem um cariz propedêutico, ao oferecer os conceitos e noções gerais necessários à compreensão do estudo do direito constitucional, descrever o percurso histórico constitucional do Brasil e introduzir questões relativas ao poder constituinte, ao direito constitucional intertemporal e aos princípios constitucionais, como república, democracia, dignidade humana, legalidade, devido processo legal, dentre outros, e seus respectivos corolários.

Em seguida, no Capítulo 6, a autora confere um enfoque privilegiado aos direitos fundamentais, sem pretensão de esgotá-los, categorizando-os com base no panorama desenvolvido pela Constituição de 1988. Detém-se ao cuidado no tratamento de questões relativas à centralidade da pessoa humana no prisma de direitos e garantias, à interpretação, à eficácia e às restrições de direitos fundamentais.

Nos Capítulos 7 a 12, Ana Paula analisa, nos seus pormenores, a organização do Estado e a Federação brasileira, sobretudo, quanto a tensões e critérios de resolução de conflitos. Não obstante proponha um estudo detalhado, tanto da separação e organização dos poderes (formação, organização, funcionamento, competências e intererrelações), como de cada um dos Poderes da República - Legislativo, Executivo e Judiciário, a autora aprofunda o estudo da Administração Pública, especialmente, os regimes jurídicos, os princípios, as regras, as noções sobre agentes públicos e outras questões correlatas.

Na sequência, o Capítulo 13 aborda a matéria relativa à ordem econômica, tributação, orçamento e finanças públicas na Constituição de 1988. O objeto da ordem econômica é analisado para investigar os fundamentos e princípios, os agentes econômicos, as modalidades e a disciplina de intervenção estatal na ordem econômica, com ênfase na regulação, no fomento e no formato de previsão de atuação direta. Sobre a tributação, são discutidas as normas que disciplinam as limitações ao poder de tributar, as competências legislativas, as espécies tributárias e a reparticipação federativa, num contexto associativo à dimensão de direitos fundamentais, limites e possibilidades do Estado e da Federação. E o texto prossegue em ordenar o exame particular do orçamento e finanças, com a finalidade de conduzir o leitor aos fundamentos dos sistemas constitucionais orçamentário e financeiro, identificando-os em correspondência a preocupações com os direitos de gerações presentes e futuras e com o controle de constitucionalidade.

O Capítulo 14 do Curso, por fim, encerra a obra jurídica pelos estudos consentâneos ao pujante e atual controle de constitucionalidade, os quais perpassam pelo desenvolvimento histórico, classificações de inconstitucionalidade, modelos clássicos e categorias de controle 
judicial ou quase-judicial e pelo sistema brasileiro de controle de constitucionalidade pelo Poder Judiciário. É translúcido, pela leitura deste derradeiro capítulo, que a contemporaneidade do direito constitucional caminha de mãos dadas com as interpretações e aplicações engendradas pela jurisdição constitucional. Deste modo, a leitura desse ponto é fundamental para a compreensão de diversos assuntos, como o controle difuso e incidental, o controle concentrado, as ações perante o Supremo Tribunal Federal, os efeitos das decisões, e mesmo, a própria discussão sobre a legitimidade do controle de constitucionalidade.

Desta feita, no ano em que a Constituição de 1988 completa 30 anos de promulgação, o Curso de Direito Constitucional (2018), de Ana Paula de Barcellos, expõe didaticamente o conteúdo e sistema jurídico constitucional, percorrendo um caminho minucioso no tratamento das principais questões.

Como afirma Ana Paula, em sua nota introdutória, trata-se do fruto de um projeto gestado como resultado de anos de trabalho, pesquisa e contribuições de mestres e alunos. Se outras obras da autora já figuram como leitura fundamental para a compreensão de temas como princípios constitucionais, eficácia jurídica, direitos fundamentais, direitos sociais, democracia e políticas públicas, este Curso vem no sentido de se firmar como obra essencial, no campo do Direito Constitucional, para os acadêmicos e profissionais do Direito. 